\title{
Mouse Strain Differences in Opiate Reward Learning Are Explained by Differences in Anxiety, Not Reward or Learning
}

\author{
Colleen L. Dockstader and Derek van der Kooy \\ Department of Anatomy and Cell Biology, University of Toronto, Toronto, Ontario, M5S 1 A8 Canada
}

Gene-targeting techniques to produce null mutations provide a powerful method for evaluating the contribution of particular candidate genes involved in motivation. The embryonic stem cell lines in which homologous recombination is undertaken are derived from 129 mice, but because of the impoverished performance of 129 mice on a number of behavioral tasks, mice chimeric for the mutation are often bred with a C57BL/6 mouse strain. Thus, an examination of both parental strains is important in the study of the knock-out mice. Although the C57BL/6 behavioral phenotype is well documented, details of the 129 phenotype have not been the focus of study until recently. We investigated opiate motivation in both 129/SvJ and C57BL/6J mouse strains to determine whether, and under what circumstances, the 129/SvJ mouse exhibited motivated behavior toward opiates. 129/SvJ mice required both drug and contextual cues to demonstrate morphine conditioned place preferences on test day, whereas $\mathrm{C} 57 \mathrm{BL} / 6 \mathrm{~J}$ mice required only contextual cues to express opiate place conditioning. Pentobarbital and diazepam but not saline, cocaine, or naloxone could substitute for morphine on test day in $129 / \mathrm{SvJ}$ mice, demonstrating that morphine indeed has rewarding motivational valence in the $129 / S v J$ mouse strain. This critical, interoceptive cue in 129/ SvJ mice on test day may be the anxiolytic properties of the effective drugs. Therefore, some deficits observed in 129 mice and mice harboring this genetic background may be attributed to high levels of anxiety during the retrieval period rather than to sensory, learning, or motivational deficits.

Key words: 129/SvJ; C57BL6/J; strain differences; knock-out mice; anxiety; opiates
Using gene-targeting techniques to create knock-out mice, one can analyze the contribution of a gene by examining the behavior of an animal on certain tasks in the absence of that gene. Recently, there has been an upsurge of awareness in the mouse genetics community with respect to the parental background of knock-out mice, indicating that not all mouse strains are created equal and that careful attention must be paid to the genetic contribution of a knock-out mouse before deriving conclusions based on its phenotype (Crawley, 1996; Crusio, 1996; Gerlai, 1996; Lathe, 1996; Crawley et al., 1997; Silva et al., 1997). Historically, viable knock-out mutations have been produced using embryonic stem cells from the 129 mouse strain, with the $129 / \mathrm{SvJ}$ strain being most commonly used (Melton, 1994; Simpson et al., 1997). Unfortunately, some 129 strains tend to perform poorly on an abundance of behavioral paradigms (Crawley et al., 1997; Balogh et al., 1999). Variation between the different 129 substrains also exists both genetically speaking (Simpson et al., 1997) and phenotypically speaking (Owen et al., 1997; Gould and Wehner, 1999). Because of their significant deficits, 129 offspring (germline chimeric for a mutation) are often backcrossed to other, more behaviorally proficient mouse strains such as C57BL/6 or DBA mice. Despite backcrossing, a number of 129 genes linked to the targeted mutation will be maintained and considerable strain differences may contribute to the varied responses of knock-out mice in specific behavioral paradigms. Thus,

\footnotetext{
Received April 2, 2001; revised Aug. 20, 2001; accepted Sept. 6, 2001.

This research was supported by the Canadian Institutes of Health Research.

Correspondence should be addressed to Colleen L. Dockstader, Department of Anatomy and Cell Biology, Medical Sciences Building, Room 1105, University of Toronto, 1 King's College Circle, Toronto, Ontario, M5S 1A8 Canada. E-mail: colleen.dockstader@utoronto.ca.

Copyright (C) 2001 Society for Neuroscience $\quad 0270-6474 / 01 / 219077-05 \$ 15.00 / 0$
}

it is important to examine both parental strains when developing behavioral assays for knock-out mice.

Only a limited body of literature exists on the rewarding effects of psychoactive drugs in 129 mouse strains, and this may be attributable to the relatively poor performance of 129 mice in the paradigms used to assess reward (Miner, 1997; Kuzmin and Johansson, 2000). 129 strains also differ in their physiological response to drugs of abuse (Miner, 1997; Crabbe et al., 1998; Homanics et al., 1998, 1999; Schlussman et al., 1998; Kuzmin and Johansson, 2000) compared with their C57BL/6 counterparts. Thus, it may be that these basic, physiological differences inherent in the 129 mouse strains may underlie motivational differences toward drugs of abuse, or it may be that sensorimotor, learning, or other behavioral deficits in 129 mice prevent them from demonstrating drug reward.

We characterized the phenotype of the $129 / \mathrm{SvJ}$ mouse strain in opiate motivation and conducted analyses of opiate motivation in both $\mathrm{C} 57 \mathrm{BL} / 6 \mathrm{~J}$ and $129 / \mathrm{SvJ}$ mouse strains to examine the individual differences that may contribute to the varied responses of knock-out mice in specific behavioral paradigms. We find that morphine is indeed rewarding in the $129 / \mathrm{SvJ}$ mouse strain at both low and high doses, although using the conditioned placepreference paradigm with this mouse strain requires a drug cue on test day to elicit a motivational response. An excessive amount of anxiety may occlude the ability to show morphine conditioned place preference on test day in drug-free $129 / \mathrm{SvJ}$ mice, because administering drugs with anxiolytic properties before the test period evokes such a preference in this strain.

\section{MATERIALS AND METHODS}

Animals. A total of 192 young, adult male 129/SvJ mice (recently renamed 129X1/SvJ by The Jackson Laboratory, Bar Harbor, ME) and C57BL/6J mice (25-35 gm; also from The Jackson Laboratory) were 
housed in groups of four in plastic mouse cages in a sound-attenuated room at a temperature of $22^{\circ} \mathrm{C}$ with lights on from 7:00 A.M. to 7:00 P.M. Food and water were available ad libitum throughout the experiments. All procedures were performed in accordance with the ethical standards set by both the University of Toronto Animal Care Committee and the Faculty Advisory Committee on Animal Services (Toronto, Canada).

Place conditioning apparatus. The place conditioning apparatus consisted of two environments that differed in color and texture, each measuring $15 \times 15 \times 15 \mathrm{~cm}$. One environment consisted of a black box with a smooth, black Plexiglas floor; the other environment was a white box with a white, wire mesh floor. A removable metal wall separated the two boxes, and each side was painted with the corresponding color. The ceiling of each box was made of removable, clear Plexiglas. Time and activity levels were recorded using three pairs of photobeams set $4 \mathrm{~cm}$ apart in each box.

Conditioned place preference. The animals were subjected to unbiased place conditioning procedures (no baseline bias in preferences for the two conditioning environments in either strain) using a standard place conditioning procedure (Mucha and Walker, 1987; Dockstader et al., 2001). Immediately before the conditioning trials, in a counterbalanced manner, both C57BL/6J and 129/SvJ mice were given an intraperitoneal injection of either 1 or $10 \mathrm{mg} / \mathrm{kg}$ morphine and exposed to one of the two conditioning environments for a $15 \mathrm{~min}$ period. The low dose of morphine is just above the threshold producing place conditioning and the high dose produces a near-maximal response in place conditioning (our unpublished observations). On the alternate day, animals were given an injection of saline and exposed to the alternate environment for $15 \mathrm{~min}$. Animals received one conditioning trial per day and the conditioning procedure was repeated until each subject had received four pairings in each environment. Both treatment compartment and order of drug presentation were counterbalanced within groups. After the final conditioning trials, mice were allowed to rest uninterrupted in their home cage for 1 week until test day. Pilot studies in both 129/SvJ and C57BL/6J strains showed that similar sizes of $10 \mathrm{mg} / \mathrm{kg}$ morphine conditioned place preferences were seen at testing either at $24 \mathrm{hr}$ or at 1 week after conditioning trials $\left(129 / \mathrm{SvJ}\right.$ mice: $t_{(1,14)}=0.15, p>0.05$; C57BL6/J mice: $\left.t_{(1,14)}=0.3, p>0.05\right)$. On test day, the animals were given a 10 min test trial with equal access to both boxes simultaneously by removing the shared wall. Animals subjected to saline (drug-free) conditions on test day were given saline immediately before being tested $(n=8 /$ strain per conditioning dose). Animals subjected to morphine on test day received 2 test days: on the first test day, one-half of the animals were administered morphine at the same dose that they received during the conditioning trials and one-half received only saline immediately before the test period ( $n=8 /$ strain per conditioning dose). On the second test day, the conditions were switched such that the animals who received morphine on the first test now received saline and vice versa. Animals showed no order effects on test day regardless of whether they were administered morphine or saline on the first day (data not shown). Time and locomotor activity in each environment were recorded over a $10 \mathrm{~min}$ period for all animals. Data were collapsed for saline-tested animals so that each saline group on test day had a total of $n=16$.

Switching morphine doses on test day. Conditioning and testing procedures mimicked those of animals receiving 2 test days in the previous experiment. Again, both $129 / \mathrm{SvJ}(n=8 /$ treatment) and C57BL $/ 6 \mathrm{~J}(n=$ $8 /$ treatment) mice were examined. This time, the morphine dose given before testing was different from the dose that they received during the conditioning periods. If animals were conditioned with $1 \mathrm{mg} / \mathrm{kg}$ morphine, they were given $10 \mathrm{mg} / \mathrm{kg}$ morphine on the drug test; conversely, if animals were conditioned with $10 \mathrm{mg} / \mathrm{kg}$ morphine, they were given 1 $\mathrm{mg} / \mathrm{kg}$ morphine on the drug test.

Investigating other drug cues on test day. The conditioning procedures for the $129 / \mathrm{SvJ}$ and C57BL/6J mice were as described previously, but only $10 \mathrm{mg} / \mathrm{kg}$ morphine was administered during the conditioning trials. Testing procedures imitated those of the previous two-test experiment. On the drug test, the morphine administered was replaced with either naloxone $(1.0 \mathrm{mg} / \mathrm{kg}$, s.c.) $(n=16 / \mathrm{strain})$ or cocaine $(10 \mathrm{mg} / \mathrm{kg}, \mathrm{i} . \mathrm{p}).(n=$ 16/strain) immediately before testing or with diazepam (2 mg/kg, i.p.) $(n=8 / \mathrm{strain})$ or pentobarbital $(10 \mathrm{mg} / \mathrm{kg}$, i.p. $)(n=8 / \mathrm{strain}) 30 \mathrm{~min}$ before testing. The doses chosen were considered to be the optimal behaviorally effective doses as demonstrated by Vaccarino et al. (1992) (naloxone), Shimosato and Ohkuma (2000) (cocaine), Crabbe et al. (1998) (diazepam), and Lister (1987) (pentobarbital).

Locomotor assays. Conditioned locomotion was assessed in $129 / \mathrm{SvJ}$ and C57BL/6J mice during the test trials investigating other drug cues on the test day. The locomotor responses to each of the drugs administered were evaluated by recording the number of photobeam activations when the mice were given equal access to both conditioning environments during the test period.

Drugs. Morphine sulfate and cocaine hydrochloride (both from University of Toronto Drug Dispensary, Toronto, Canada), naloxone hydrochloride (Sigma-Aldrich, Oakville, Ontario, Canada), and sodium pentobarbital (MTC Pharmaceuticals, Cambridge, Ontario, Canada) were dissolved in a $0.9 \%$ saline solution at a concentration of $1 \mathrm{ml} / \mathrm{kg}$ Diazepam was dissolved in $12.5 \%$ 2-hydroxypropyl- $\beta$-cyclodextrin (both from Sigma-Aldrich), also at a concentration of $1 \mathrm{ml} / \mathrm{kg}$. All experimental groups were injected at a volume of $1 \mathrm{ml} / \mathrm{kg}$.

\section{RESULTS}

\section{$129 / \mathrm{SvJ}$ mice require both drug and contextual cues on test day to demonstrate morphine reward: context alone is not sufficient}

The behavior of $129 / \mathrm{SvJ}$ and C57BL/6J mice was examined in morphine conditioned place preference assays to determine whether genetic differences in mouse strains evoked behavioral differences in place conditioning paradigms and, if so, if these differences could be ameliorated. On test day, the $129 / \mathrm{SvJ}$ mice showed morphine place preference when pretreated with morphine but not when pretreated with saline. We demonstrated this by exposing previously drug-naive C57BL/6J and 129/SvJ mouse strains to both a low- or high-dose morphine-paired environment and a saline-paired environment over a series of conditioning trials. Animals were tested either drug-free (saline on test day), as in the traditional paradigm, or in the presence of morphine. A three-way ANOVA revealed a significant interaction between strain, conditioning dose, and test condition $\left(F_{(1,88)}=4.19 ; p<\right.$ $0.05)$. C57BL/6J mice preferred the morphine-paired environments when tested under the influence of either saline or morphine on test day. $129 / \mathrm{SvJ}$ mice spent significantly more time in the high-dose morphine-paired environment when tested under the influence of the same high dose on test day compared with testing under saline conditions $\left(t_{(1,22)}=3.38 ; p<0.01\right)$. However, in $129 / \mathrm{SvJ}$ mice conditioned with the lower morphine dose, neither saline nor low-dose morphine treatment on test day revealed preferences (Fig. 1). Neither strain showed a baseline preference for either environment in the absence of conditioning (Fig. 1, inset). Although 129/SvJ mice found morphine rewarding (at least at the higher dose), they required both drug and contextual cues on test day to demonstrate morphine reward.

\section{A low dose of morphine has motivational value but does not provide a sufficient drug cue on test day to elicit a motivational response}

Was the high, but not the low, dose of morphine rewarding in $129 / \mathrm{SvJ}$ mice, or was it that both doses were rewarding but only the high dose provided a sufficient drug cue on test day? We examined both mouse strains conditioned with a low dose of morphine and tested with a high dose of morphine or conditioned with a high dose of morphine and tested with a low dose of morphine. The C57BL/6J mice showed strong conditioned place preference regardless of the drug or test dose of morphine. The $129 / \mathrm{SvJ}$ mice demonstrated morphine reward when they were conditioned with a low dose of morphine and tested with a high dose of morphine but not when they were conditioned with a high dose of morphine and tested with a low dose of morphine $\left(t_{(1,14)}=2.15 ; p<0.05\right)$ (Fig. 2). Both low and high doses were rewarding in the $129 / \mathrm{SvJ}$ strain, but only a high dose provided an effective cue on test day. 


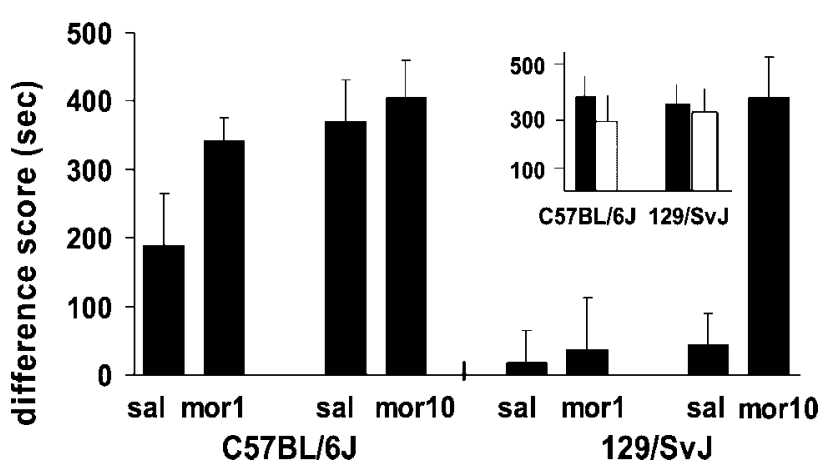

Figure 1. Conditioned place preferences induced by conditioning doses of morphine at 1 and $10 \mathrm{mg} / \mathrm{kg}$ administered intraperitoneally in C57BL/6J and 129/SvJ mice, tested after saline or morphine injections: animals given morphine on test day were given a dose that corresponded to their conditioning dose. Thus, the first saline ( $\mathrm{sal}$ ) data (on the left for each strain) correspond to the same mice also given $1 \mathrm{mg} / \mathrm{kg}$ morphine on the test day and conditioned with $1 \mathrm{mg} / \mathrm{kg}$ morphine during training (mor1). The second saline data correspond to the same mice also given 10 $\mathrm{mg} / \mathrm{kg}$ morphine on the test day and conditioned with $10 \mathrm{mg} / \mathrm{kg}$ morphine during training (mor10). Data represent the mean difference scores + SEM of the time spent in morphine-paired environments minus the time spent in saline-paired environments during testing. Inset, Untreated baseline mean times + SEM (in seconds) spent in the black and white environments during a 10 min period by separate groups of C57BL/6J $(n=8)$ and $129 / \mathrm{SvJ}(n=8)$ mice. Black bars indicate time spent in the black environment and white bars indicate time spent in the white environment.

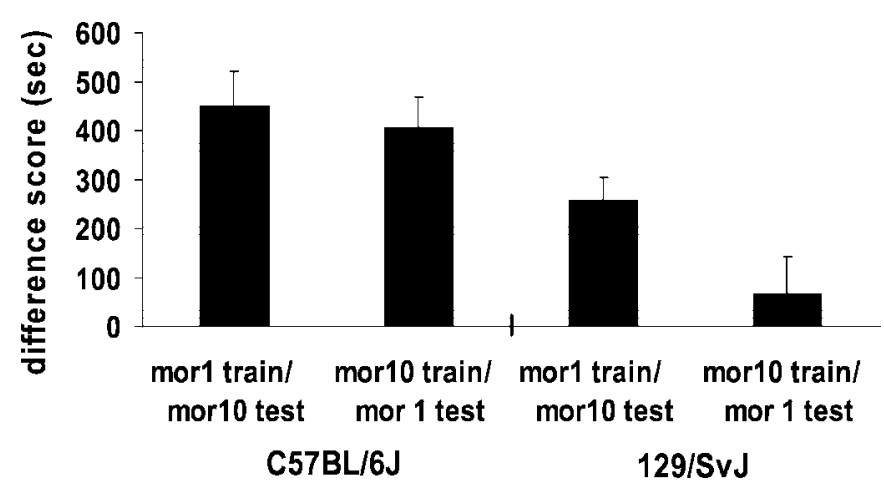

Figure 2. Conditioned place preferences induced by conditioning doses of $1 \mathrm{mg} / \mathrm{kg}$ morphine (administered intraperitoneally) with $10 \mathrm{mg} / \mathrm{kg}$ morphine (also administered intraperitoneally) on test day (mor1 train/ mor10 test) or by conditioning doses of $10 \mathrm{mg} / \mathrm{kg}$ morphine with $1 \mathrm{mg} / \mathrm{kg}$ morphine on test day (mor10 train/mor1 test) in C57BL/6J and 129/SvJ mice. Data represent the mean difference scores + SEM of the time spent in morphine-paired environments minus the time spent in saline-paired environments during testing.

\section{The effective drug cue on test day is neither opiate- specific nor related to locomotor changes in $129 /$ SvJ mice}

We examined the nature of the effectiveness of the drug cue on test day by administering drugs that varied in motivational valence, anxiolytic or anxiogenic properties, and the ability to increase or decrease locomotion on test day. A two-way ANOVA revealed a main effect of drug given on test day $\left(F_{(1,116)}=2.299\right.$; $p<0.05)$ and a significant interaction between strain and drug treatment on test day $\left(F_{(5,116)}=2.88 ; p<0.05\right)$. Although C57BL/6J mice displayed morphine conditioned place preference under the influence of all drugs tested, they showed a reduction in their preference, compared with saline-tested animals, when pre-

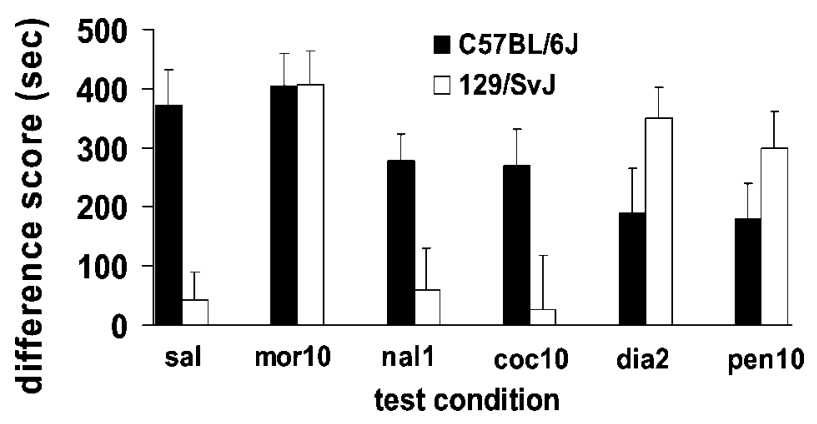

Figure 3. Conditioned place preferences induced by conditioning doses of morphine at $10 \mathrm{mg} / \mathrm{kg}$ in C57BL/6J and $129 / \mathrm{SvJ}$ mice. Animals were given morphine $(10 \mathrm{mg} / \mathrm{kg})$ (mor10), naloxone $(1.0 \mathrm{mg} / \mathrm{kg})$ (nal1), cocaine $(10 \mathrm{mg} / \mathrm{kg})(\operatorname{coc} 10)$, diazepam $(2 \mathrm{mg} / \mathrm{kg})($ dia $)$, or pentobarbital $(10$ $\mathrm{mg} / \mathrm{kg}$ ) ( pen10) on one test day; on the alternate test day they were given saline ( $(\mathrm{s} a \mathrm{l}$ ). Data represent the mean difference scores + SEM of the time spent in morphine-paired environments minus the time spent in salinepaired environments during testing. Saline data represent means + SEM of all five saline test trials for each strain.

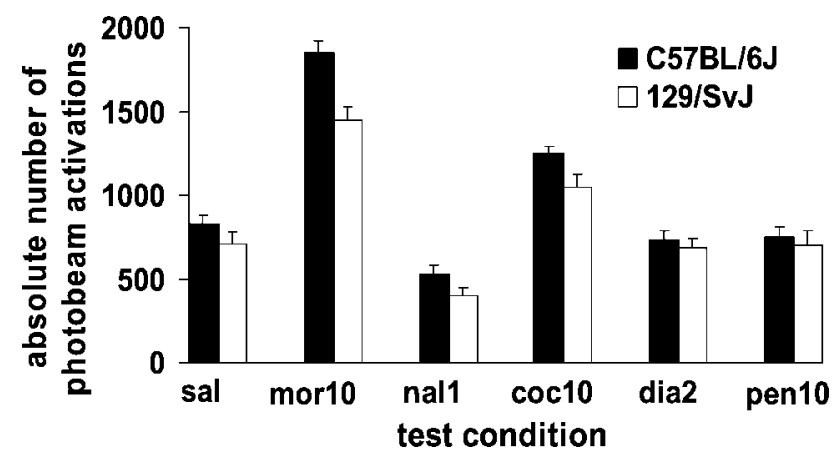

Figure 4. Locomotor activity on test day in C57BL/6J and 129/SvJ mice conditioned with morphine $(10 \mathrm{mg} / \mathrm{kg})$. Animals injected with morphine $(10 \mathrm{mg} / \mathrm{kg})($ mor10), naloxone $(1.0 \mathrm{mg} / \mathrm{kg})($ nal1 $)$, cocaine $(10 \mathrm{mg} / \mathrm{kg})$ (coc10), diazepam $(2 \mathrm{mg} / \mathrm{kg})($ dia 2$)$, or pentobarbital $(10 \mathrm{mg} / \mathrm{kg})$ ( pen10) were given the drug before testing on one test day; on the alternate test day they were given saline. Data represent means + SEM of absolute numbers of photobeam activations during testing. Saline data represent means + SEM of all five saline test trials for each strain.

treated with naloxone, cocaine, diazepam, or pentobarbital before testing. However, none of these comparisons in C57BL/6J mice reached statistical significance. $129 / \mathrm{SvJ}$ mice not only displayed morphine conditioned place preference when conditioned with morphine and tested with morphine, compared with salinetested animals $\left(t_{(1,11)}=4.01 ; p<0.01\right)$, but they also demonstrated morphine place conditioning when tested with diazepam $\left(t_{(1,11)}=3.76 ; p<0.01\right)$ or pentobarbital $\left(t_{(1,11)}=2.87 ; p<0.05\right)$. They did not show place conditioning when tested with naloxone or cocaine (Fig. 3). Because both diazepam and pentobarbital (in addition to morphine) provided sufficient drug cues on test day in both $\mathrm{C} 57 \mathrm{BL} / 6 \mathrm{~J}$ and $129 / \mathrm{SvJ}$ mice, the effectiveness of the drug cue was not opiate-specific.

Drug-induced conditioned locomotion was also assessed during the test period and revealed that locomotor effects did not correlate with the expression of rewarding effects. A two-way ANOVA revealed a main effect of $\operatorname{strain}\left(F_{(1,116)}=7.17 ; p<\right.$ $0.01)$ and of drug given on test day $\left(F_{(5,116)}=53.85 ; p<0.001\right)$ but no significant interaction. In both the C57BL/6J and 129/SvJ strains, morphine $\left[\left(t_{(1,11)}=8.59 ; p<0.001\right)\right.$ and $\left(t_{(1,11)}=6.42\right.$; $p<0.001)$, respectively] and cocaine $\left[\left(t_{(1,19)}=2.29 ; p<0.05\right)\right.$ and $\left(t_{(1,19)}=2.38 ; p<0.05\right)$, respectively] increased locomotion 
during testing significantly more than saline pretreatment; naloxone $\left[\left(t_{(1,19)}=2.267 ; p<0.05\right)\right.$ and $\left(t_{(1,19)}=3.268 ; p<0.05\right)$, respectively] significantly reduced locomotion (Fig. 4). Because morphine and cocaine increased locomotion, naloxone decreased locomotion, and diazepam and pentobarbital had no effect in both C57BL/6J and 129/SvJ mice, locomotor activity did not correlate with the expression of opiate reward. Animals remained active throughout the $10 \mathrm{~min}$ test period. Activity, per unit time, was similar in both compartments, suggesting that activity cannot artifactually explain conditioned place preference.

\section{DISCUSSION}

\section{Both internal and external cues are critical to elicit motivated behavior in the $129 / \mathrm{SvJ}$ strain}

The place conditioning paradigm is a valuable method for examining genetic influences involved in motivated behavior toward drugs of abuse (Cunningham et al., 1999; Ledent et al., 1999; Dockstader et al., 2001, Risinger et al., 2001). Using the placepreference assay within the parameters of a traditional place conditioning paradigm, we demonstrate that $129 / \mathrm{SvJ}$ mice did not show a morphine place preference when tested drug-free. One may attribute a lack of morphine place preference in the $129 / \mathrm{SvJ}$ mouse strain (or in progeny derived from this strain) to sensorimotor, learning, or motivational impairments. This would not be a surprising conclusion given the irregularities in this strain that may contribute to phenotypic variation (Livy and Wahlsten, 1991; Wahlsten and Ozaki, 1994; Owen et al., 1997; Homanics et al., 1999). Importantly, we demonstrated that both low and high doses of morphine were rewarding to this strain, yet only the high dose of morphine on test day provided sufficient cues to elicit a motivational response. This distinguishes between the motivational value of morphine and its effectiveness as an interoceptive (internal) cue in the $129 / \mathrm{SvJ}$ strain. Although the $129 / \mathrm{SvJ}$ strain found morphine rewarding, both contiguous drug cues and cues of the conditioning environment were required on test day to demonstrate a preference. Others have shown that the presence of internal cues may be as critical as the presence of external cues in evoking a conditioned response (Bespalov et al., 1999; Kim et al., 1999). This is consistent with the present data demonstrating that not only is morphine rewarding in the $129 / \mathrm{SvJ}$ strain but that other critical psychological factors are needed on test day to reveal the conditioned reward.

\section{Anxiety occludes retrieval of opiate conditioned place preference in 129/SvJ mice}

What is the nature of the drug cue on test day that reveals the opiate learning in 129/SvJ mice? Morphine acts as a learned discriminative cue (Skinner and Martin, 1992; Jaeger and van der Kooy, 1996), has anxiolytic effects (Costall et al., 1989), has powerful motivational effects (Matthes et al., 1996; David and Cazala, 2000; Narita et al., 2000; Dockstader et al., 2001), and alters locomotion in drug activation (Browne and Segal, 1980; Mickley et al., 1990; Kuribara, 1996). It may be that any of these effects aids the animal in the retrieval of information learned during the conditioning period.

One interpretation of the data is that, on test day, morphine serves as a reminder cue of the conditioning period. We observed that morphine, diazepam, and pentobarbital provided effective cues in eliciting morphine conditioned place preference, whereas naloxone and cocaine did not. Diazepam and pentobarbital, in addition to morphine, evoked conditioned place preferences in $129 / \mathrm{SvJ}$ mice; however, the stimulus effects of diazepam and pentobarbital do not generalize to morphine, as revealed in previous drug discrimination assays (Tang and Franklin, 1991). Therefore, the efficacy of morphine on test day in the $129 / \mathrm{SvJ}$ strain was not an opiate-specific effect; suggesting that the drug cue on test day did not act as a specific conditioned reminder of the training period. It is possible that naloxone, in blocking endogenous opioid activity, served to block the conditioned place preference on test day, but this is an unlikely explanation because endogenous opioid activity was not sufficient to elicit a motivational response as observed in saline-injected $129 / \mathrm{SvJ}$ animals on test day. Moreover, naloxone on test day did not block preferences for a morphine-paired environment in C57BL/6J mice. The efficacy of the drug cue on test day is also unlikely to be a specific motivational effect, because cocaine, at a dose that is rewarding (Shimosato and Ohkuma, 2000), and naloxone, at a dose that is aversive (Vaccarino et al., 1992), had no significant effects on morphine place preference in C57BL/6J or $129 / \mathrm{SvJ}$ mice. It also appears that the effectiveness of the internal cue on test day was not specific to the psychomotor stimulation effects of the drugs, because animals under the influence of naloxone (decreased locomotion) or cocaine (increased locomotion) did not demonstrate morphine conditioned place preference. Because opiatespecificity, motivational valence, or increases or decreases in locomotion did not correlate with the ability of the drug to elicit an opiate place preference on test day, we suggest that the essential cue provided on test day may be anxiolytic in nature. $129 / \mathrm{SvJ}$ mice exhibit greater levels of anxiety than their C57BL/6J counterparts, because they spend less time and show fewer entries in the open arms of an elevated plus maze and also display less locomotor behavior in an open-field assay (Homanics et al., 1999). The attenuation of anxiety induced by drugs such as morphine (Costall et al., 1989), diazepam (Pich and Samanin, 1989), and pentobarbital (Lister, 1987) may allow for the retrieval of information learned during the conditioning period in the place conditioning paradigm that would have been otherwise blocked, on test day, by high levels of anxiety in the 129/SvJ strain. Indeed cocaine, a drug with anxiogenic properties (Rogerio and Takahashi, 1992), did not permit the expression of the conditioned motivational response.

It is possible that providing an internal anxiolytic cue on test day may not be the only successful strategy to evoke place conditioning in mice. Altering trial duration (Cunningham et al., 1999), increasing trial number (Risinger et al., 2001), and inducing stress before conditioning (Cabib et al., 2000) have all been shown to facilitate the expression of motivated behavior. Providing an additional test in which an anxiolytic is administered is a simple strategy that does not require any alteration of conditioning protocol and may provide robust results in a mouse strain that shows otherwise inferior behavior.

We conclude that morphine is rewarding in the $129 / \mathrm{SvJ}$ mouse strain. Backcrossing knock-out mice with this genetic background or comparing the behavior of parental strains of knock-out mice has become critical (Crabbe et al., 1998; Kelly et al., 1998; Gould and Wehner, 1999; Rogers et al., 1999; Belzung and Barreau, 2000; van Gaalen and Steckler, 2000). Our data provide evidence that deficits observed in 129 mice (and in mice harboring this genetic background) in research examining the motivational effects of drugs of abuse may be attributed to a deficit in retrieval caused by anxiety, rather than to a specific learning or motivational deficit. 


\section{REFERENCES}

Balogh SA, McDowell CS, Stavenezer AJ, Denenberg VH (1999) A behavioral and neuroanatomical assessment of an inbred substrain of 129 mice with behavioral comparisons to C57BL/6J mice. Brain Res 836:38-48.

Belzung C, Barreau S (2000) Differences in drug-induced place conditioning between $\mathrm{BALB} / \mathrm{c}$ and $\mathrm{C} 57 \mathrm{BL} / 6$ mice. Pharmacol Biochem Behav 65:419-423.

Bespalov AY, Tokarz ME, Bowen SE, Balster RL, Beardsley PM (1999) Effects of test conditions on the outcome of place conditioning with morphine and naltrexone in mice. Psychopharmacology 141:118-122.

Browne SG, Segal DS (1980) Behavioral activating effects of opiates and opioid peptides. Biol Psychiatry 15:77-86.

Cabib S, Orsini C, LeMoal M, Piazza PV (2000) Abolition and reversal of strain differences in behavioral responses to drugs of abuse after a brief experience. Science 289:463-465.

Costall B, Jones BJ, Kelly ME, Naylor RJ, Tomkins DM (1989) Exploration of mice in a black and white test box: validation as a model of anxiety. Pharmacol Biochem Behav 32:777-785.

Crabbe JC, Gallaher EJ, Cross SJ, Belknap JK (1998) Genetic determinants of sensitivity to diazepam in inbred mice. Behav Neurosci 112:668-677.

Crawley JN (1996) Unusual behavioral phenotypes of inbred mouse strains. Trends Neurosci 19:181-182.

Crawley JN, Belknap JK, Collins A, Crabbe JC, Frankel W, Henderson N, Hitzemann RJ, Maxson SC, Miner LL, Silva AJ, Wehner JM, Wynshaw-Boris A, Paylor R (1997) Behavioral phenotypes of inbred mouse strains: recommendations for molecular studies. Psychopharmacology 132:107-124.

Crusio WE (1996) Gene-targeting studies: new methods, old problems. Trends Neurosci 19:186-187.

Cunningham CL, Dickinson SD, Grahame NJ, Okorn SD, McMullen CS (1999) Genetic differences in cocaine-induced conditioned place preference in mice depend on conditioning trial duration. Psychopharmacology 146:73-80.

David V, Cazala P (2000) Anatomical and pharmacological specificity of the rewarding effect elicited by microinjections of morphine into the nucleus accumbens of mice. Psychopharmacology 150:24-34.

Dockstader CL, Rubinstein M, Grandy DK, Low MJ, van der Kooy D (2001) The D2 receptor is critical in mediating opiate motivation only in opiate-dependent and withdrawn mice. Eur J Neurosci 13:995-1001.

Gerlai R (1996) Gene-targeting studies of mammalian behavior: is it the mutation or the background genotype? Trends Neurosci 19:177-181.

Gould TJ, Wehner JM (1999) Genetic influences on latent inhibition. Behav Neurosci 113:1291-1296.

Homanics GE, Le NQ, Kist F, Mihalek R, Hart AR, Quinlan JJ (1998) Ethanol tolerance and withdrawal responses in GABA(A) receptor $\alpha 6$ subunit null allele mice and in inbred C57BL/6J and strain 129/SvJ mice. Alcohol Clin Exp Res 22:259-265.

Homanics GE, Quinlan JJ, Firestone LL (1999) Pharmacologic and behavioral responses of inbred C57BL/6J and strain $129 / \mathrm{SvJ}$ mouse lines. Pharmacol Biochem Behav 63:21-26.

Jaeger TV, van der Kooy D (1996) Separate neural substrates mediate the motivating and discriminative properties of morphine. Behav Neurosci 110:181-201.

Kelly MA, Rubinstein M, Phillips TJ, Lessov CN, Burkhart-Kasch S, Zhang G, Bunzow JR, Fang Y, Gerhardt GA, Grandy DK, Low MJ (1998) Locomotor activity in D2 dopamine receptor-deficient mice is determined by gene dosage, genetic background, and developmental adaptations. J Neurosci 18:3470-3479.

Kim JA, Siegel S, Patenall VR (1999) Drug-onset cues as signals: intraadministration associations and tolerance. J Exp Psychol Anim Behav Process 25:491-504.

Kuribara H (1996) Effects of interdose interval on ambulatory sensitization to methamphetamine, cocaine, and morphine in mice. Eur J Pharmacol 316:1-5.

Kuzmin A, Johansson B (2000) Reinforcing and neurochemical effects of cocaine: differences among C57, DBA, and 129 mice. Pharmacol Biochem Behav 65:399-406.

Lathe R (1996) Mice, gene targeting, and behavior: more than just genetic background. Trends Neurosci 19:183-186.

Ledent C, Valverde O, Cossu G, Petitet F, Aubert JF, Beslot F, Bohme GA, Imperato A, Pedrazzini T, Roques BP, Vassart G, Fratta W,
Parmentier M (1999) Unresponsiveness to cannabinoids and reduced addictive effects of opiates in CB1 receptor knockout mice. Science 283:401-404

Lister RG (1987) The use of a plus-maze to measure anxiety in the mouse. Psychopharmacology 92:180-185.

Livy DJ, Wahlsten D (1991) Tests of genetic allelism between four inbred mouse strains with absent corpus callosum. J Hered 82:459-464

Matthes HW, Maldonado R, Simonin F, Valverde O, Slowe S, Kitchen I, Befort K, Dierich A, Le Meur M, Dolle P, Tzavara E, Hanoune J, Roques BP, Kieffer BL (1996) Loss of morphine-induced analgesia, reward effect, and withdrawal symptoms in mice lacking the $\mu$-opioid receptor gene. Nature 383:819-823.

Melton DW (1994) Gene targeting in the mouse. BioEssays 16:633-638.

Mickley GA, Mulville MA, Postler MA (1990) Brain $\mu$ and $\delta$ opioid receptors mediate different locomotor hyperactivity responses of the C57BL/6J mouse. Psychopharmacology 101:332-337.

Miner LL (1997) Cocaine reward and locomotor activity in C57BL/6J and 129/SvJ inbred mice and their F1 cross. Pharmacol Biochem Behav 58:25-30.

Mucha RF, Walker MJ (1987) Aversive property of opioid receptor blockade in drug-naive mice. Psychopharmacology 93:483-488.

Narita M, Aoki T, Suzuki T (2000) Molecular evidence for the involvement of NR2B subunit containing $N$-methyl-D-aspartate receptors in the development of morphine-induced place preference. Neuroscience 101:601-606.

Owen EH, Logue SF, Rasmussen DL, Wehner JM (1997) Assessment of learning by the Morris water task and fear conditioning in inbred mouse strains and D1 hybrids: implications of genetic background for single gene mutations and quantitative trait loci analyses. Neuroscience 80:1087-1099.

Pich M, Samanin R (1989) A two-compartment exploratory model to study anxiolytic/anxiogenic effects of drugs in the rat. Pharmacol Res 21:595-602.

Risinger FO, Freeman PA, Greengard P, Fienberg AA (2001) Motivational effects of ethanol in DARPP-32 knockout mice. J Neurosci 21:340-348.

Rogerio R, Takahashi RN (1992) Anxiogenic action of acute but not repeated cocaine administration in handling-habituated mice in the plus-maze test. Braz J Med Biol Res 25:713-716.

Rogers DC, Jones DN, Nelson PR, Jones CM, Quilter CA, Robinson TL, Hagan JJ (1999) Use of SHIRPA and discriminant analysis to characterise marked differences in the behavioural phenotype of six inbred mouse strains. Behav Brain Res 105:207-217.

Schlussman SD, Ho A, Zhou Y, Curtis AE, Kreek MJ (1998) Effects of "binge" pattern cocaine on stereotypy and locomotor activity in C57BL/6J and 129/J mice. Pharmacol Biochem Behav 60:593-599.

Shimosato K, Ohkuma S (2000) Simultaneous monitoring of conditioned place preference and locomotor sensitization following repeated administration of cocaine and methamphetamine. Pharmacol Biochem Behav 66:285-292.

Silva AJ, Simpson EM, Takahashi JS, Lipp H-P, Nakanishi S, Wehner JM, Giese KP, Tully T, Abel T, Chapman PF, Fox K, Grant S, Itohara S, Lathe R, Mayford M, McNamara JO, Morris RJ, Piciotto M, Roder J, Shin H-S, Slesinger PA, Storm DR, Stryker MP, Tonegawa S, Wang Y, Wolfer DP (1997) Mutant mice and neuroscience: recommendations concerning genetic background. Banbury Conference on Genetic Background in Mice. Neuron 19:755-769.

Simpson EM, Linder CC, Sargent EE, Davisson MT, Mobraaten LE, Sharp JJ (1997) Genetic variation among 129 substrains and its importance for targeted mutagenesis in mice. Nat Genet 16:19-27.

Skinner DM, Martin GM (1992) Conditioned taste aversions support drug discrimination learning at low dosages of morphine. Behav Neural Biol 58:236-241.

Tang AH, Franklin SR (1991) The discriminative stimulus effects of diazepam in rats at two training doses. J Pharmacol Exp Ther 258:926-931

Vaccarino AL, Plamondon H, Melzack R (1992) Analgesic and aversive effects of naloxone in BALB/c mice. Exp Neurol 117:216-218.

van Gaalen MM, Steckler T (2000) Behavioural analysis of four mouse strains in an anxiety test battery. Behav Brain Res 115:95-106.

Wahlsten D, Ozaki HS (1994) Defects of the fetal forebrain in acollosal mice. In: Callosal agenesis (Lassonde M, Jeeves MA, eds), pp 125-134 New York: Plenum. 